\title{
Diets rich in starch increase the posthepatic availability of amino acids in dairy cows fed diets at low and normal protein levels
}

\author{
G. Cantalapiedra-Hijar, ${ }^{* 1}$ S. Lemosquet, †¥ J. M. Rodriguez-Lopez, ${ }^{*}$ F. Messad, ${ }^{*}$ and I. Ortigues-Marty \\ *Institut National de la Recherche Agronomique, UMR 1213 INRA-VetAgroSup, Unité Mixte de Recherches sur les Herbivores, \\ 63122 St Genès Champanelle, France \\ †INRA, UMR 1348 PEGASE, F-35590 Saint-Gilles, France \\ ‡Agrocampus Ouest, UMR1348 PEGASE, F-35000 Rennes, France
}

\begin{abstract}
Five mid-lactation multicatheterized Jersey cows were used in a $4 \times 4$ Latin square design to investigate whether the increase in milk $\mathrm{N}$ yield associated with diets rich in starch versus fiber could originate from changes in the splanchnic AA metabolism and if these changes depended upon the dietary crude protein $(\mathrm{CP})$ content. Four isoenergetic diets were formulated to provide 2 different carbohydrate compositions [diets rich in starch (350 g of starch and $310 \mathrm{~g}$ of neutral detergent fiber $/ \mathrm{kg}$ of dry matter) versus rich in fiber ( $45 \mathrm{~g}$ of starch and $460 \mathrm{~g}$ of neutral detergent fiber $/ \mathrm{kg}$ of dry matter)] crossed by 2 different CP contents (12.0 vs. $16.5 \% \mathrm{CP}$ ). At the end of each treatment period, 6 hourly blood samples were collected from the portal and hepatic veins as well as the mesenteric artery to determine net nutrient fluxes across the portal-drained viscera (PDV), liver, and total splanchnic tissues. Dry matter and calculated energy intake as well as total absorbed energy were similar across treatments. However, the net portal appearance (NPA) of acetate, total volatile fatty acids, and $\beta$-hydroxybutyrate were higher with diets rich in fiber versus starch, whereas that of oxygen, glucose, butyrate, and insulin were lower. Concomitant to these changes, the percentage of $\mathrm{N}$ intake recovered as total AA (TAA) in the portal vein was lower for diets rich in fiber versus starch (42.3 vs. $51.4 \%$, respectively), without, however, any difference observed in the NPA of the main AA used as energy fuels by the PDV (Glu, Gln, and Asp). Despite a higher NPA of TAA with starch versus fiber diets, no differences in the net hepatic flux of TAA, essential and nonessential AA were observed, resulting in a higher $(+22 \%)$ net splanchnic release of $\mathrm{AA}$ and, hence, a greater $(+7 \%)$ milk $\mathrm{N}$ yield. The net hepatic flux and hepatic fractional removal of none of the individual AA was affected as the main carbohydrate changed from fiber to starch, except for Gly and
\end{abstract}

Received February 5, 2014.

Accepted April 25, 2014.

${ }^{1}$ Corresponding author: gonzalo.cantalapiedra@clermont.inra.fr
Lys, which were higher for the latter. After correcting for differences in NPA of TAA, the net hepatic uptake of TAA tended to be lower with starch versus fiber diets. The higher transfer of $\mathrm{N}$ from feed to milk with diets rich in starch is not the consequence of a direct sparing AA effect of glucogenic diets but rather the result of lower energy requirements by the PDV along with a higher microbial $\mathrm{N}$ flow to the duodenum. A better AA use by peripheral tissues with starch versus fiber diets was also hypothesized but more studies are warranted to clarify this issue.

Key words: milk N efficiency, splanchnic metabolism, amino acid, energy source

\section{INTRODUCTION}

The efficiency of dietary $\mathrm{N}$ conversion into milk $\mathrm{N}$ is of particular concern for the dairy industry, because it affects profit margins and has an impact on environmental N pollution (Castillo et al., 2001). At similar energy and $\mathrm{N}$ intakes, diets rich in starch have been shown by meta-analysis to slightly improve milk $\mathrm{N}$ efficiency in dairy cows compared with diets rich in fiber (North European data set in Huhtanen and Hristov, 2009). Similarly, we have recently shown that highstarch diets improved the milk $\mathrm{N}$ efficiency compared with high-fiber diets, especially when they were formulated at low $(12.0 \% \mathrm{CP})$ compared with normal $(16.5 \%$ $\mathrm{CP}$ ) dietary $\mathrm{N}$ levels (Cantalapiedra-Hijar et al., 2014). These findings suggest that the dietary carbohydrate (CHO) composition has an effect on the transfer of $\mathrm{N}$ from feed into milk beyond the current energy and protein feed values, but little evidence exists in the literature on the mechanism that may be involved.

The splanchnic tissues [i.e., portal-drained viscera (PDV) and liver], as a result of their many important functions and their high rate of metabolism, have high requirements for $\mathrm{AA}$, which may limit the systemic availability of absorbed AA to the peripheral tissues (Reynolds, 2006). Anatomically, the splanchnic tissues are positioned between AA intestinal absorption and 
utilization by peripheral tissues. Hence, diet-induced differences in milk $\mathrm{N}$ efficiency may originate from splanchnic adaptations.

A mechanism traditionally evoked to explain the higher efficiency of $\mathrm{N}$ use with starch has been a sparing effect of glucogenic nutrients on AA utilization by the gastrointestinal tract (Nocek and Tamminga, 1991; Freetly et al., 2010) and liver (Danfær et al., 1995), the spared AA being available for peripheral tissues. Other metabolic adaptations could be involved, such as lower energy expenditure and protein turnover of the gastrointestinal tract as the proportion of dietary fiber decreases (Reynolds et al., 1991a) or lower splanchnic AA catabolism mediated by changes in the hormonal status promoted by glucogenic diets (Brockman, 1990). Recently, no sparing effect of glucogenic nutrients on splanchnic AA removal was demonstrated when using high-protein diets (18-19\% CP) in postpartum transition dairy cows (Larsen and Kristensen, 2012). However, data obtained in monogastrics showed a reduction in the splanchnic AA oxidation at the expense of other energy substrates when animals were fed diets at low compared with high $\mathrm{N}$ levels (van der Schoor et al., 2001), suggesting that the sparing effect of glucogenic nutrients on AA catabolism could be enhanced when the supply of $\mathrm{N}$ is limited.

We hypothesized that increasing the gastrointestinal absorption of glucogenic nutrients in dairy cows by feeding diets rich in starch would (1) decrease the net AA removal by the PDV and liver, (2) increase the net posthepatic availability of absorbed AA, and (3) increase the milk protein secretion compared with the absorption of ketogenic nutrients from fiber-rich diets, and that this effect would be more evident at low than at normal dietary $\mathrm{N}$ levels. Thus, the aim of this study was to evaluate the effects of the $\mathrm{CHO}$ (starch vs. fiber) on nutrients appearing in the portal circulation, their net hepatic uptake and milk performances in dairy cows fed isoenergetic diets at low $(12.0 \% \mathrm{CP})$ versus normal $(16.5 \% \mathrm{CP}) \mathrm{N}$ levels.

\section{MATERIALS AND METHODS}

The experiment was conducted in respect of the national legislation on animal care (Certificate of Authorisation to Experiment on Living Animals, no. 004495; Ministry of Agriculture, Paris, France).

\section{Animals, Experimental Design, and Dietary Treatments}

Five multiparous Jersey cows in mid lactation, averaging $365 \pm 28 \mathrm{~kg}$ of BW and $78 \pm 12 \mathrm{DIM}$ at the onset of the experiment, were used in a $4 \times 4$ Latin square design, with the fifth cow used as an extra observation. Chronic indwelling catheters were surgically implanted before the lactation peak and at least 5 wk before the beginning of the experiment. The surgical procedure was adapted from that described by Ortigues et al. (1994) in sheep. Briefly, polyvinyl chloride catheters (Dow Corning Corp., Midland, MI) were implanted into the portal vein (i.d. $=1.5 \mathrm{~mm}$; o.d. $=2.5 \mathrm{~mm}$ ) by a transhepatic surgical approach, as well as into 2 mesenteric arteries (i.d. $=1.1 \mathrm{~mm}$; o.d. $=1.9 \mathrm{~mm}$ ), 1 ruminal and 1 mesenteric vein (i.d. $=1.1 \mathrm{~mm}$; o.d. $=$ $1.9 \mathrm{~mm}$ ) and the hepatic vein (i.d. $=1.5 \mathrm{~mm}$; o.d. $=$ $2.5 \mathrm{~mm}$ ). The surgery was conducted aseptically under general anesthesia using an oxygen-isoflurane mixture (98\% oxygen and $2 \%$ isoflurane). Catheter maintenance was carried out twice per week through physiological sterile saline containing $200 \mathrm{IU}$ of heparin. Cows were housed in tie-stalls lighted $24 \mathrm{~h}$ daily and milked twice daily in their stall at 0600 and $1700 \mathrm{~h}$. Cows were assessed and treated for pain after the surgical intervention as detailed by Paulmier et al. (2012).

Four iso- $\mathrm{NE}_{\mathrm{L}}$ diets were formulated (INRA, 2007) according to a $2 \times 2$ factorial arrangement of treatments to test the effects of dietary CP content [low $(12.0 \%)$ and normal (16.5\%), meeting 80 and $100 \%$, respectively, of the Institut national de la recherche agronomique (INRA) recommendations (246 g of protein truly digested in the small intestine/MJ; INRA 2007)] and CHO (350 g of starch and $310 \mathrm{~g}$ of NDF/ $\mathrm{kg}$ of $\mathrm{DM}$ for the starch diets, and $45 \mathrm{~g}$ of starch and $460 \mathrm{~g}$ of $\mathrm{NDF} / \mathrm{kg}$ of $\mathrm{DM}$ for the fiber diets, respectively). Diet composition (Table 1) was the same used in a previous feeding trial (Cantalapiedra-Hijar et al., 2014) and so the chemical composition (Table 2) was almost identical. Diets were supplemented with rumenprotected Met (Smartamine M; Adisseo France SAS, Antony, France) in order for all diets to approach the balanced intestinal digestible Lys and Met ratio of 3.0 (INRA, 2007).

Animals were fed fixed and limited quantities of rations throughout the experiment to achieve isoenergetic and nitrogenous intakes across dietary treatment. Dietary allowances were calculated to meet $100 \%$ of the cow average net energy requirements at the middle of the trial as detailed elsewhere (Cantalapiedra-Hijar et al., 2014). Each experimental period lasted 28 d. To minimize postprandial variations, feeds (except grass hay) were hand mixed and offered from automated feeders in equal meals every $3 \mathrm{~h}$ from d 1 through 24 and hourly from d 24 to 28 . Grass hay was separately distributed 3 times per day $(25 \%$ at $0800 \mathrm{~h}, 25 \%$ at $1200 \mathrm{~h}$, and $50 \%$ at $1700 \mathrm{~h}$ ). Water was freely available to all cows. Feeds offered were weighed daily and the DM content of feeds was analyzed twice weekly to 
Table 2. Chemical composition and feed values of diets

\begin{tabular}{|c|c|c|c|c|}
\hline \multirow[b]{2}{*}{ Item } & \multicolumn{2}{|c|}{ Low CP (12.0\%) } & \multicolumn{2}{|c|}{ Normal CP (16.5\%) } \\
\hline & Starch & Fiber & Starch & Fiber \\
\hline \multicolumn{5}{|c|}{ Diet chemical composition, $\mathrm{g} / \mathrm{kg}$ of $\mathrm{DM}$} \\
\hline $\mathrm{OM}$ & 950 & 928 & 951 & 921 \\
\hline $\mathrm{CP}$ & 118 & 121 & 160 & 169 \\
\hline NDF & 317 & 467 & 305 & 458 \\
\hline $\mathrm{ADF}$ & 156 & 287 & 154 & 285 \\
\hline Starch $^{1}$ & 334 & 59 & 357 & 29 \\
\hline Ether extract ${ }^{1}$ & 32 & 25 & 28 & 26 \\
\hline \multicolumn{5}{|c|}{ Feed value, / $\mathrm{kg}$ of DM } \\
\hline $\mathrm{NE}_{\mathrm{L}}, \mathrm{MJ}$ & 7.15 & 7.02 & 7.06 & 6.95 \\
\hline $\mathrm{PDIE}^{2} \mathrm{~g}$ & 82.5 & 85.0 & 96.5 & 98.2 \\
\hline \multicolumn{5}{|c|}{ AADI, ${ }^{3} \%$ of PDIE } \\
\hline AlaDI & 6.9 & 6.8 & 6.7 & 6.7 \\
\hline $\mathrm{ArgDI}$ & 4.7 & 4.6 & 4.8 & 4.7 \\
\hline AspDI & 11.0 & 11.1 & 10.9 & 11.1 \\
\hline GluDI & 13.6 & 13.1 & 14.1 & 13.4 \\
\hline HisDI & 2.0 & 2.0 & 2.0 & 2.1 \\
\hline IleDI & 5.4 & 5.4 & 5.3 & 5.3 \\
\hline LeuDI & 8.6 & 8.5 & 8.7 & 8.5 \\
\hline LysDI & 7.1 & 7.2 & 6.9 & 7.1 \\
\hline MetDI $^{4}$ & 2.3 & 2.4 & 2.5 & 2.6 \\
\hline PheDI & 5.1 & 5.1 & 5.1 & 5.1 \\
\hline ProDI & 4.6 & 4.6 & 4.6 & 4.7 \\
\hline SerDI & 4.7 & 4.8 & 4.8 & 4.9 \\
\hline ThrDI & 5.3 & 5.3 & 5.2 & 5.2 \\
\hline TyrDI & 4.4 & 4.6 & 4.4 & 4.4 \\
\hline ValDI & 5.8 & 6.0 & 5.7 & 5.8 \\
\hline
\end{tabular}

${ }^{1}$ From ingredients pooled from period 1 to $4(\mathrm{n}=1)$.

${ }^{2} \mathrm{PDIE}=$ protein digestible in the small intestine when rumen fermentable energy is limiting.

${ }^{3} \mathrm{AADI}=\mathrm{AA}$ digestible in the small intestine; $1 \mathrm{~g}$ of AADI is equal to $1 \mathrm{~g}$ of PDIE.

${ }^{4}$ The percentage MetDI was estimated after Smartamine M (Adisseo France SAS, Antony, France) supplementation. The MetDI from the basal diet was 2.0 and $1.9 \%$, for starch and fiber diets at low CP levels, respectively, and 1.9 and $1.8 \%$ for starch and fiber diets at normal CP levels, respectively.

$-80^{\circ} \mathrm{C}$ for later determination of VFA (Reynolds et al., 1988) and hemoglobin using a commercial kit (Biolabo SA, Fismes, France). The blood partial pressure of $\mathrm{O}_{2}$ and $\mathrm{pH}$ were analyzed within 5 min after sampling by an automatic analyzer (ABL700 Blood Gas Analyzer; Radiometer A/S, Copenhagen, Denmark). Heparinized blood samples were deproteinized $(1: 2, \mathrm{vol} / \mathrm{vol})$ with perchloric acid $(0.6 \mathrm{M})$, centrifuged at $4,500 \times g$ for $15 \mathrm{~min}$ at $-4^{\circ} \mathrm{C}$, and the supernatant fraction stored at $-20^{\circ} \mathrm{C}$ for further analyses of glucose, L-lactate, and BHBA as detailed by Cantalapiedra-Hijar et al. (2014). The remainder of heparinized blood was separated by centrifugation $\left(1,200 \times g\right.$ for $15 \mathrm{~min}$ at $\left.4^{\circ} \mathrm{C}\right)$ to obtain the plasma and kept at $-20^{\circ} \mathrm{C}$ before analysis. The individual AA plasma concentration was assessed by isotopic dilution as described by Kraft et al. (2011). The EAA analyzed were His, Ile, Leu, Lys, Met, Phe, Thr, Tyr, and Val $(\mathrm{n}=9)$; and the NEAA analyzed were Ala, Asn, Asp, Gln, Glu, Gly, Pro and Ser (n = 8). Total AA (TAA) was the sum of EAA and NEAA. Plasma pAH was deacetylated (Rodríguez-López et al., 2014) and analyzed as described by Isserty et al. (1998). Blood from EDTA tubes were kept at $-20^{\circ} \mathrm{C}$ for urea- $\mathrm{N}$ analysis (by a diacetyl monoxime direct assay; Ormsby, 1942) and ammonia-N determination (Ngo et al., 1982) within the first $18 \mathrm{~h}$ after sampling. Plasma obtained from the remainder of EDTA-blood was used for insulin (RIA; MP Biomedicals, Illkirch, France), NEFA (C WAKO kit; Unipath SA, Dardilly, France), and triglyceride (kit by Sobioda laboratories, Grenoble, France) determinations.

\section{Calculations and Statistical Analysis}

Plasma flows across the PDV were calculated from downstream dilution of pAH according to Katz and Bergman (1969). Plasma flow was divided by $1-(0.01$ $\times$ hematocrit) to calculate blood flow. Daily mean blood (or plasma) concentrations, blood (or plasma) flow, and net nutrient fluxes were calculated for each cow $\times$ treatment. Net nutrient fluxes were obtained by multiplying the mean $(\mathrm{n}=6)$ venous-arterial difference by the mean $(n=6)$ blood or plasma flow of the appropriate tissue bed [net portal appearance (NPA) for the PDV, net hepatic flux (NHF) for the liver, and net splanchnic release (NSR) for total splanchnic tis- 
sues]. A negative net flux indicates net tissue removal, whereas a positive value denotes net release.

Whole-blood $\mathrm{O}_{2}$ concentration was calculated using the following equation: $\mathrm{O}_{2}(\mathrm{~mL} / \mathrm{mL})=(\mathrm{Hb} \times 1.34 \times \%$ sat $\left.\mathrm{O}_{2}\right)+\left(0.023 \times \mathrm{pO}_{2}\right)$, where $\mathrm{Hb}$ is blood hemoglobin $(\mathrm{g} / \mathrm{L}), 1.34$ is $\mathrm{mL}$ of $\mathrm{O}_{2} / \mathrm{g}$ of hemoglobin, \% sat $\mathrm{O}_{2}$ is the saturation percentage of $\mathrm{O}_{2}$ calculated according to the equation by Kelman (1966), and $\mathrm{pO}_{2}$ is the partial pressure of $\mathrm{O}_{2}$. The volume of oxygen $(\mathrm{mL})$ was transformed into mass $(\mathrm{mmol})$ assuming that $22.4 \mathrm{~L}$ of $\mathrm{O}_{2}$ at standard temperature and pressure equals $1 \mathrm{~mol}$ of $\mathrm{O}_{2}$. Heat production was calculated as $20.44 \mathrm{~kJ} / \mathrm{L}$ of $\mathrm{O}_{2}$ consumed. Total absorbed energy was calculated as the addition of net energy fluxes (NPA or NSR) based on the sum of heats of combustion of nutrients whose net flux are positive and PDV or total splanchnic tissue heat production. Thus, any negative net flux, including for individual AA, was regarded as zero for the energy summation. The ME intake was calculated according to the Agricultural Research Council (ARC, 1984; ME $=15.54 \times$ digestible $\mathrm{OM}$ intake) and using digestibility data obtained from a previous feeding trial using the same diets as in the current study (Cantalapiedra-Hijar et al., 2014).

Dietary MP [protein truly digestible in the small intestine when the rumen fermentable energy is limiting (PDIE), in the French system] was calculated as detailed by Cantalapiedra-Hijar et al. (2014), whereas the AA composition of the calculated MP was estimated as proposed by Rulquin et al. (2001) from the rumenundegradable feed protein digestible in the intestine and the analyzed AA composition of feed ingredients.

A linear mixed-effects model that included a random intercept term for each cow was used. The mixed model was fitted using the LME procedure within the nlme package (Pinheiro et al., 2008) in R software (R Development Core Team, 2009). Statistical analyses were carried out as a $4 \times 4$ Latin square, following the model $\mathrm{Y}_{\mathrm{ijk} \mathrm{l}}=\mu+\mathrm{CHO}_{\mathrm{l}}+\mathrm{CP}_{\mathrm{k}}+\mathrm{CHO} \times \mathrm{CP}_{\mathrm{kl}}+\mathrm{P}_{\mathrm{i}}+\mathrm{C}_{\mathrm{j}}$ $+\varepsilon_{\mathrm{ijk} k}$, where $\mathrm{Y}_{\mathrm{ijkl}}$ is the dependent variable, $\mu$ is the overall mean, $\mathrm{P}_{\mathrm{i}}$ is the fixed effect of the experimental period i, $\mathrm{C}_{\mathrm{j}}$ is the random effect of cow $\mathrm{j}, \mathrm{CHO}_{1}$ is the fixed effect of dietary carbohydrate composition (starch vs. fiber), $\mathrm{CP}_{\mathrm{k}}$ is the fixed effect of dietary $\mathrm{CP}$ concentration (low vs. normal), $\mathrm{CHO} \times \mathrm{CP}_{\mathrm{kl}}$ is the fixed effect of the 2-way interaction between $\mathrm{CP}$ and $\mathrm{CHO}$, and $\varepsilon_{\mathrm{ijk}}$ is the random residual error, which was assumed to be $\mathrm{N}\left(0, \sigma^{2}\right)$. Mean values are reported as least squares means with pooled standard error of the mean values ( $\mathrm{n}=5$ for PDV data and arterial concentrations and $\mathrm{n}=4$ for NHF and NSR data) because of missing observations. To assess whether at similar NPA of TAA (NPA-TAA; general predictor) the NHF of TAA (NHF-TAA) was further affected by $\mathrm{CHO}$, residuals from the regression equation (NHF-TAA against NPATAA) were analyzed for the effect of the CHO by oneway ANOVA. Statistical significance was declared as $P$ $\leq 0.05$ and trends at $P \leq 0.10$.

\section{RESULTS}

All catheters remained patent for blood sampling throughout the experiment in 3 out of 5 animals. One cow did not complete the last period due to an acute lameness before the completion of the last treatment (normal CP-fiber diet) and no data for this cow $\times$ period was available. In addition, 1 cow did not have a functional hepatic vein catheter in the last 2 periods (low CP-starch diet and normal CP-starch diet), and another cow for the last period (normal CP-starch diet). Therefore, $\mathrm{n}=5$ for arterial concentrations and net flux across PDV (except for the normal CP-fiber diet, where $\mathrm{n}=4$ ), $\mathrm{n}=4$ for liver and splanchnic net flux (except for the normal CP-starch diet, where $\mathrm{n}=$ 3 , and for the low $\mathrm{CP}$-fiber diet, where $\mathrm{n}=5$ ).

\section{Feed Intake and N Partitioning}

Body weight of animals remained similar across dietary treatments $(P>0.05)$. As planned, the DM and energy (calculated $\mathrm{ME}$ and theoretical $\mathrm{NE}_{\mathrm{L}}$ ) intakes (Table 3$)$ were similar across treatments $(P>0.05)$. The NDF and ADF intakes were higher $(P<0.001)$ and starch intake lower $(P<0.001)$ for fiber compared with starch diets. On the other hand, CP and MP intakes were higher $(P<0.001)$ at normal versus low $\mathrm{CP}$ levels.

Milk $\mathrm{N}$ and true protein yield was higher with starch versus fiber diets (around $+7 \% ; P \leq 0.046$ ) and at normal versus low $\mathrm{CP}$ levels (around $+32 \% ; P<0.001$ ). Although the milk $\mathrm{N}$ efficiency (milk $\mathrm{N}$ yield/ $\mathrm{N}$ intake) increased by around 2.4 percentage points, on average (around $+8 \%$ of increase) with diets rich in starch versus fiber, this effect was not found to be significant $(P$ $=0.13)$. In contrast, low-CP diets tended $(P=0.069)$ to promote a greater milk $\mathrm{N}$ efficiency (milk $\mathrm{N} / \mathrm{N}$ intake) compared with normal-CP diets. The theoretical milk efficiency of digestible AA (milk true protein yield relative to theoretical MP intake above maintenance requirements) did not vary across treatments $(P>0.05)$ and was slightly lower $(59.2 \pm 2.48 \%)$ than the $64 \%$ assumed by the INRA (2007) feeding system.

\section{Blood and Plasma Flow and Arterial Concentrations}

Packed cell volume and blood and plasma flow across PDV, liver, and total splanchnic tissues (Table 4) were 
Table 3. Feed intake, milk N yield, and urinary N excretion in lactating Jersey cows fed the experimental $\operatorname{diets}^{1}$

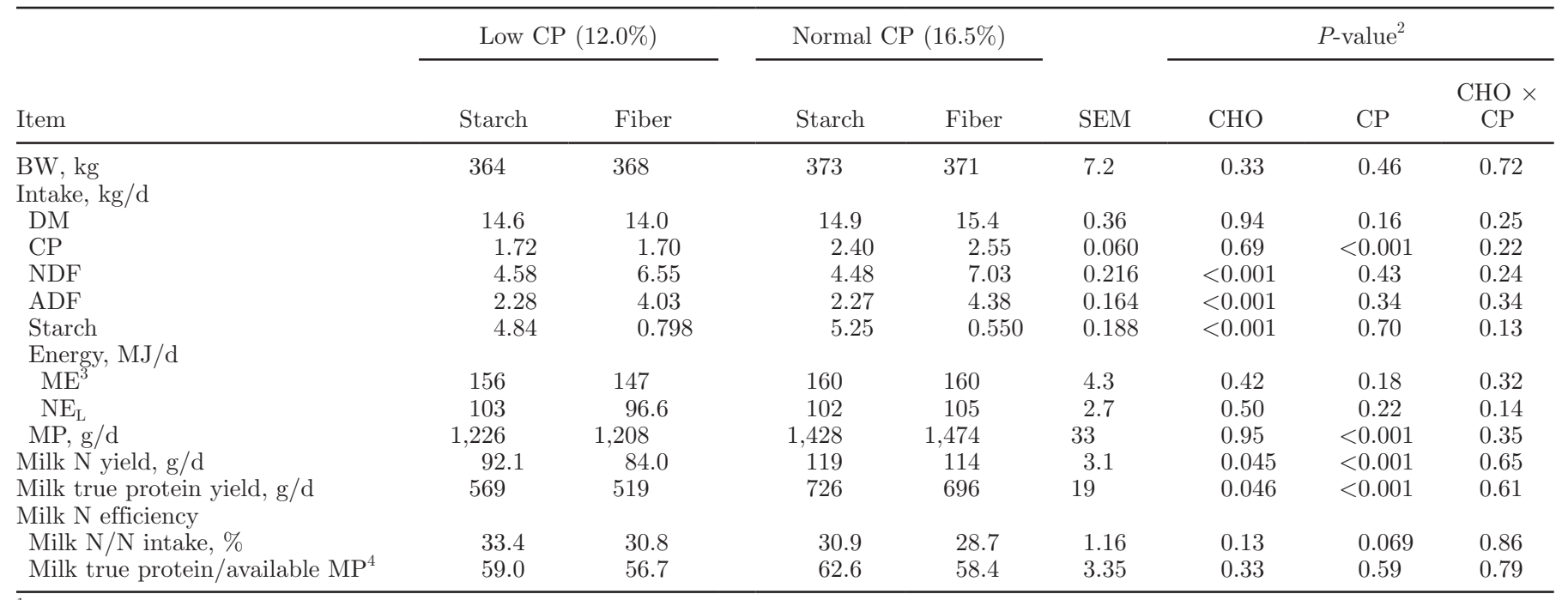

${ }^{1}$ Least squares means presented with pooled SEM $(\mathrm{n}=5)$.

${ }^{2} \mathrm{CHO}=$ effect of dietary carbohydrate (starch or fiber); $\mathrm{CP}=$ effect of $\mathrm{CP}$.

${ }^{3}$ Metabolizable energy intake estimated with digestibility data from Cantalapiedra-Hijar et al. (2014) and the equation (ME intake = digestible OM intake $\times 15.58$ ) proposed by the Agricultural Research Council (ARC, 1984).

${ }^{4}$ Available MP $=$ MP intake - MP for maintenance (INRA, 2007).

similar across dietary treatments $(P>0.05)$. In our experimental conditions (deacetylation of plasma pAH), the average contribution of the hepatic artery to the total hepatic flow was around $8.2 \%$ (data not shown) without any effect of $\mathrm{CHO}$ or $\mathrm{CP}$ on hepatic arterial flow $(P \geq 0.46)$.

Diets rich in starch promoted lower arterial concentrations (Table 4$)$ of total VFA $(P=0.003)$ and acetate $(P=0.002)$ and higher concentrations of butyrate $(P$ $=0.024)$ and insulin $(P=0.003)$ compared with diets rich in fiber. Arterial concentrations of glucose, propionate, lactate, BHBA, NEFA, triglycerides, oxygen, ammonia-N, urea-N, and TAA-N were not affected by $\mathrm{CHO}(P \geq 0.12)$. Concerning the effect of $\mathrm{CP}$ content, normal-CP diets only increased the arterial concentration of urea- $\mathrm{N}(P<0.001)$ and insulin $(P=0.002)$ and decreased that of NEFA $(P=0.007)$ compared with low-CP diets.

Among the individual AA, the arterial concentrations of His, Pro, and Asn were higher $(P \leq 0.075)$ and those of Phe and Met lower $(P \leq 0.074)$ with starch versus fiber diets. With normal-CP diets, the arterial concentration was higher for EAA as well as for His, Met, Pro, and Val $(P \leq 0.020)$ and lower for Gly $(P$ $=0.011)$ compared with low-CP diets. Finally, a CHO $\times \mathrm{CP}$ interaction was noted for the arterial concentrations of EAA and BCAA as well as for Ala, Phe, Leu, Ile, and Val, which were all higher in fiber versus starch diets, but only at normal CP levels $(P \leq 0.096)$.

\section{Net Fluxes Across PDV, Liver, and Total Splanchnic Tissues}

Net portal appearance was lower $(P \leq 0.052)$ for total VFA, acetate, propionate, and BHBA and higher $(P$ $\leq 0.055$ ) for glucose, butyrate, and insulin with starch versus fiber diets (Table 5). Moreover, starch diets promoted higher $(P \leq 0.054)$ NPA of TAA-N, NEAA-N, EAA-N, and branched-chain AA-N (BCAA-N) compared with fiber diets, whereas similar values were obtained $(P>0.523)$ for ammonia-N and urea-N (Table 6). Concerning the individual AA (Table 6), starch diets only increased the NPA of Leu $(P=0.037)$, and tended to increase the NPA of Val, Pro, Phe, and His $(P \leq 0.087)$.

The dietary carbohydrate composition did not affect the NHF of any metabolite $(P \geq 0.11)$ except Gly $(P=$ $0.038)$ and Lys $(P=0.039)$, whose values were higher (lower net hepatic uptake) for starch versus fiber diets. The NHF of TAA-N as a percentage of their NPA increased numerically by $22 \%$, on average, when changing the main $\mathrm{CHO}$ from fiber to starch, but this effect was found to be nonsignificant $(P \geq 0.18)$. However, a tendency for starch diets $(P=0.091)$ to have higher NHF (lower uptake) of TAA was found (Figure 1) when standardizing data at similar NPA (residuals analysis; Figure 1b). Diets rich in starch did not modify the fractional removal of any individual AA by the liver, except for Gly and Lys, whose hepatic removal was 
Table 4. Blood and plasma flow and arterial concentration of metabolites in lactating Jersey cows fed the experimental diets ${ }^{1}$

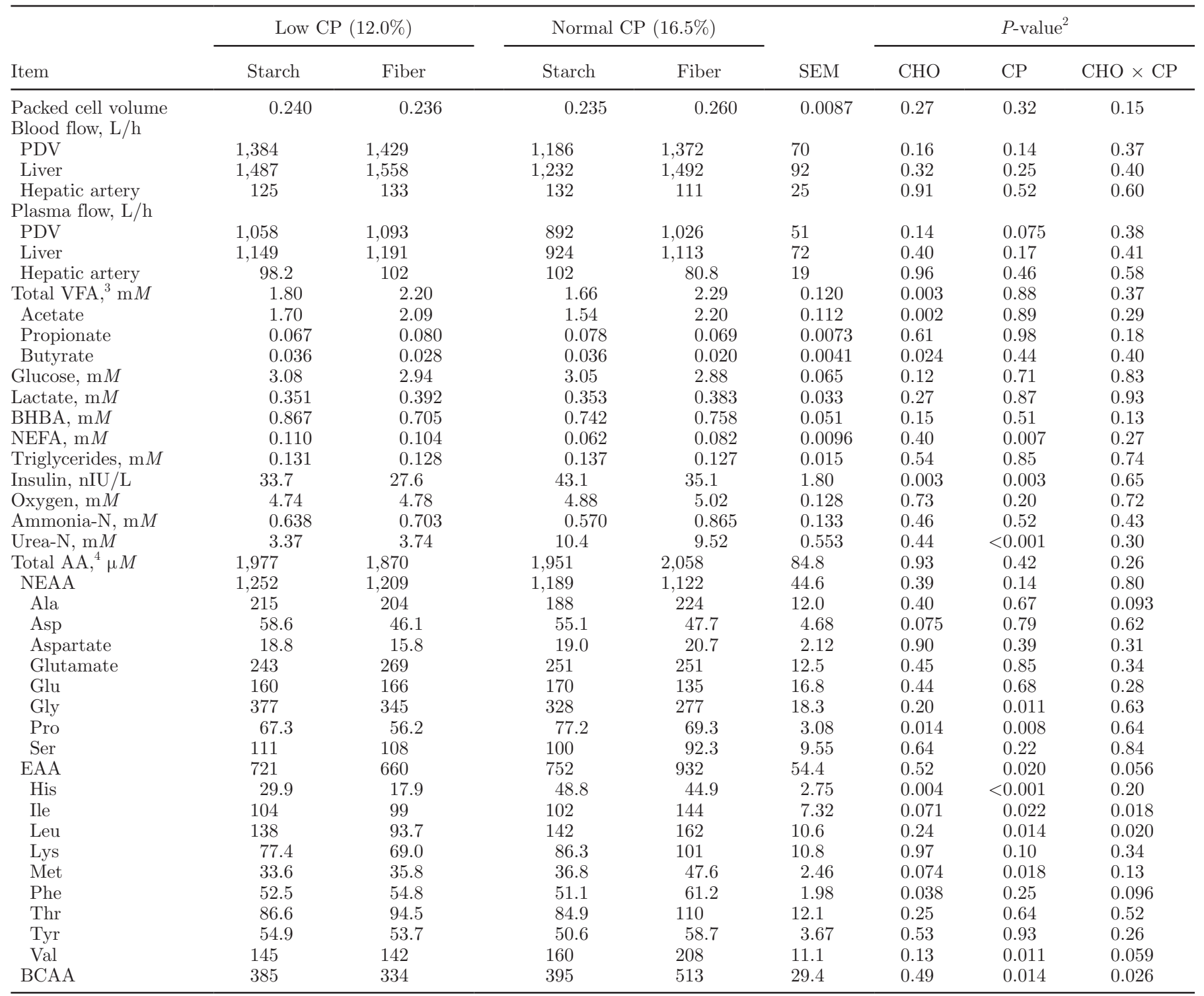

${ }^{1}$ Least squares means presented with pooled SEM $[\mathrm{n}=5$ for arterial concentrations and plasma and blood flow for portal drained viscera (PDV), and $\mathrm{n}=4$ for plasma and blood flow for the liver and hepatic artery].

${ }^{2} \mathrm{CHO}=$ effect of dietary carbohydrate (starch or fiber); $\mathrm{CP}=$ effect of $\mathrm{CP}$.

${ }^{3}$ Total $\mathrm{VFA}=$ acetate + propionate + butyrate.

${ }^{4}$ Total amino acids $=$ NEAA + EAA; NEAA = Ala, Pro, Ser, Asp, Glu, Asn, Gly, and Gln; EAA = His, Met, Phe, Tyr, Ile, Leu, Lys, Thr, and Val; BCAA = branched-chain AA (Leu, Ile, and Val).

higher for fiber versus starch diets $(P=0.010)$. The CHO affected the NSR of butyrate, TAA-N, NEAAN, EAA-N, BCAA-N, Leu, Lys, and Thr, which were all higher with starch versus fiber diets $(P \leq 0.058)$. Finally, the effect of $\mathrm{CHO}$ was still significant when the NPA $(P=0.006)$ and NSR $(P=0.038)$ of TAA-N were expressed as a proportion of $\mathrm{N}$ intake.

As the dietary CP content increased from 12.0 to $16.5 \%$, the net flux across the PDV and total splanchnic tissues increased $(P \leq 0.038)$, whereas that across the liver decreased $(P \leq 0.062)$ for urea-N, TAA-N, NEAA$\mathrm{N}, \mathrm{EAA}-\mathrm{N}$, and BCAA-N. In the case of ammonia-N, for diets at normal CP content, its NPA increased $(P$ $=0.004)$ and NHF decreased $(P=0.004)$ compared with low-CP diets, whereas its NSR remained similar $(P=0.64)$. In addition, normal- versus low-CP diets decreased the NHF and NSR of BHBA, but only in starch diets $(\mathrm{CHO} \times \mathrm{CP} ; P \leq 0.042)$. Concerning the individual AA, normal-CP diets increased the NPA of all AA $(P \leq 0.086)$ except Ala $(P=0.28)$; the NHF of 
Table 5. Net portal appearance (NPA), net hepatic flux (NHF), and net splanchnic release (NSR) of VFA, glucose, lactate, BHBA, NEFA, triglycerides, oxygen, and insulin in lactating Jersey cows fed the experimental diets ${ }^{1}$

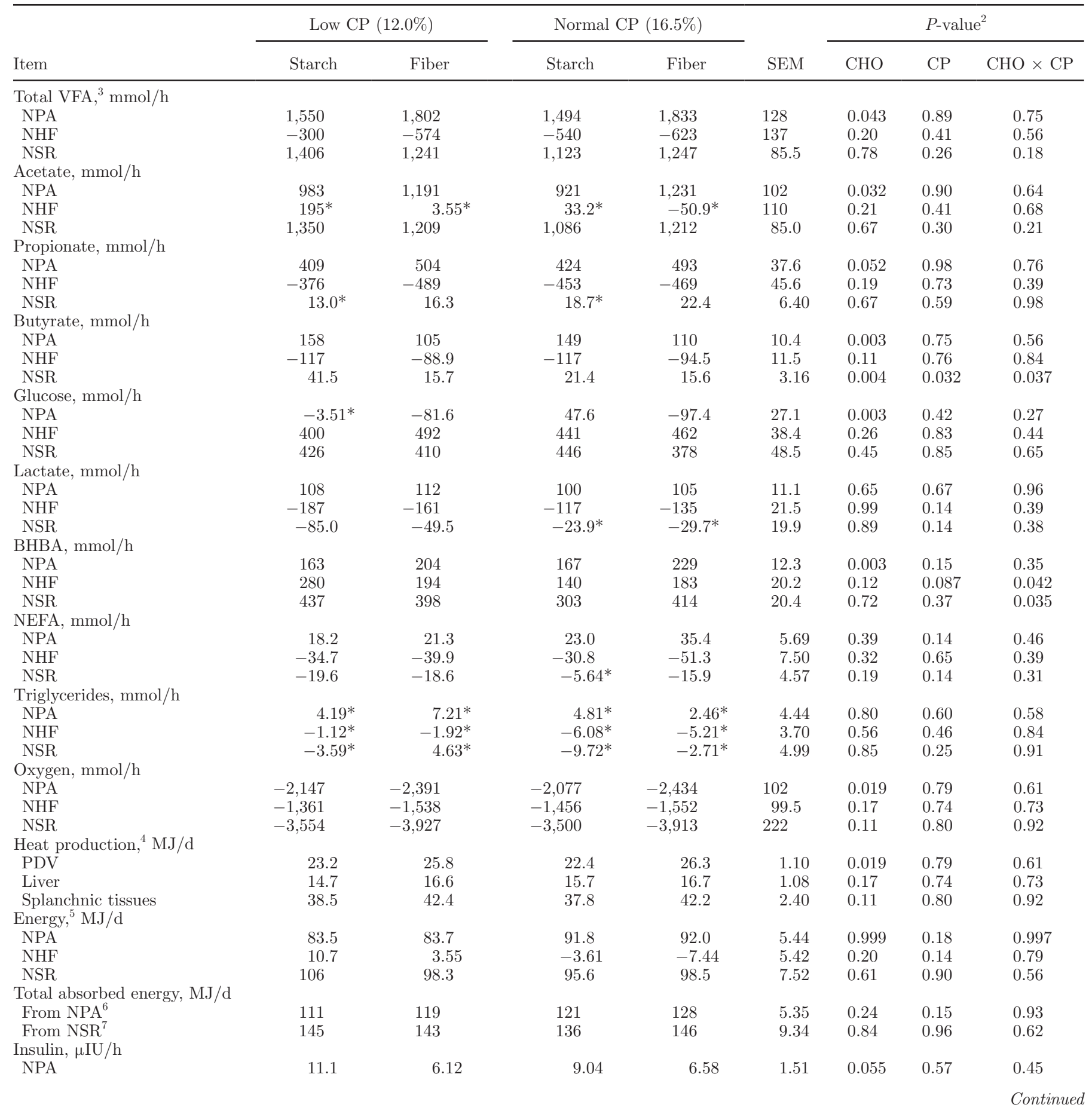

all AA $(P \leq 0.096)$ except for Ser $(P=0.10)$, Glu $(P$ removal increased for TAA-N, NEAA-N, and EAA-N $=0.17)$, Gly $(P=0.30)$, Met $(P=0.49)$, and Val $(P \quad(P \leq 0.071)$ as well as for Pro, Ser, Gly, Gln, Phe, Tyr, $=0.46) ;$ and the NSR of Gly, His, Phe, Ile, Leu, Thr, and Val $(P \leq 0.081)$ compared with low-CP diets. As the dietary $\mathrm{CP}$ content increased, the hepatic fractional
Leu, Lys, and Thr $(P \leq 0.092)$.

The PDV $\mathrm{O}_{2}$ consumption and heat production decreased $(+14 \% ; P=0.019)$ with starch versus fiber 
Table 5 (Continued). Net portal appearance (NPA), net hepatic flux (NHF), and net splanchnic release (NSR) of VFA, glucose, lactate, BHBA, NEFA, triglycerides, oxygen, and insulin in lactating Jersey cows fed the experimental diets ${ }^{1}$

\begin{tabular}{|c|c|c|c|c|c|c|c|c|}
\hline Item & \multicolumn{2}{|c|}{ Low CP $(12.0 \%)$} & \multicolumn{2}{|c|}{ Normal CP $(16.5 \%)$} & SEM & \multicolumn{3}{|c|}{$P$-value ${ }^{2}$} \\
\hline $\mathrm{NHF}$ & -7.16 & -3.94 & -7.95 & -3.14 & 1.85 & 0.13 & 0.94 & 0.71 \\
\hline
\end{tabular}

${ }^{1}$ Least squares means presented with pooled SEM $[\mathrm{n}=5$ for portal drained viscera (PDV) data, and $\mathrm{n}=4$ for NHF and NSR data $]$.

${ }^{2} \mathrm{CHO}=$ effect of dietary carbohydrate (starch or fiber); $\mathrm{CP}=$ effect of $\mathrm{CP}$.

${ }^{3}$ Total VFA $=$ acetate + propionate + butyrate.

${ }^{4}$ Heat production calculated as $4.89 \mathrm{kcal} / \mathrm{L}$ of $\mathrm{O}_{2}$ consumed (McLean, 1972).

${ }^{5}$ Net fluxes of energy, based on individual heats of combustion $(\mathrm{MJ} / \mathrm{mol})$, across the portal drained viscera (NPA) and splanchnic tissues (NSR): acetate $=0.875$, propionate $=1.54$, butyrate $=2.19$, glucose $=2.81, \mathrm{BHBA}=2.06$, lactate $=1.37, \mathrm{NEFA}=11.28$, urea $=0.64$, Ala $=1.58$, Pro $=2.74$, Ser $=1.45$, Asp $=1.60$, Glu $=2.24$, Asn $=1.93$, Gly $=0.97$, Gln $=2.57$, His $=3.18$, Met $=2.92$, Phe $=4.65$, Tyr $=4.43$, Ile $=$ $3.58, \mathrm{Leu}=3.58, \mathrm{Lys}=3.68, \mathrm{Thr}=2.05$, and $\mathrm{Val}=2.92$

${ }^{6}$ Total absorbed energy from the gastrointestinal tract calculated from PDV fluxes = summation of net energy flux (based on individual heats of combustion) across the PDV, for which net flux is positive + heat production of PDV.

${ }^{7}$ Total absorbed energy from the gastrointestinal tract calculated from NSR fluxes $=$ summation of net energy fluxes (based on individual heats of combustion) across the total splanchnic tissues + heat production of total splanchnic tissues.

*Net fluxes not different from $0(P<0.05)$ according to the asymptotic CI within each treatment.

diets and remained similar $(P=0.79)$ between normaland low-CP diets. However, neither the net flux of $\mathrm{O}_{2}$ (and thus the energy expenditure) of the liver nor that of total splanchnic tissues was affected by treatments $(P>0.05)$. The total absorbed energy from the gastrointestinal tract was similar $(P>0.05)$ across dietary treatments as well as the gross energy flux across the splanchnic tissues $(P>0.05)$, calculated both from PDV and total splanchnic tissues measures.

\section{DISCUSSION}

To improve current feeding systems, nutrient supply and utilization must be represented at a more detailed level than the current aggregated energy and protein feed values (Nocek and Tamminga, 1991; Hanigan et al., 2005). For instance, at similar calculated net energy and protein intakes, results from the current study confirm previous findings showing a small $(+7 \%$ in the present study) but significant improvement in milk $\mathrm{N}$ yield when dairy cows were fed starch versus fiber diets (Huhtanen and Hristov, 2009; Cantalapiedra-Hijar et al., 2014). Moreover, such an improvement was accompanied by a greater availability of absorbed AA for the peripheral tissues $(+15 \%$ NSR of TAA-N) even though diets were formulated to supply similar MP. This questions the validity of reasoning only on aggregated feed values, raising the issue of whether the profile of absorbed nutrients associated with a particular diet can affect the efficiency of nutrient utilization beyond their energy and protein feed values (Leiva et al., 2000; Hanigan et al., 2005).

The high AA requirements and metabolic rate of splanchnic tissues have a profound effect on the avail- ability and profile of absorbed AA presented to peripheral tissues (Lapierre et al., 2005). Therefore, differences in milk $\mathrm{N}$ yield promoted by $\mathrm{CHO}$ could originate from changes in splanchnic AA metabolism, and, as observed in monogastrics, this phenomenon could be modulated by the N supply (van der Schoor et al., 2001). Care was taken in diet formulation to minimize the effect of potential interfering factors on AA metabolism and animal performance, and so energy and $\mathrm{N}$ intake as well as the Lys:Met ratio in MP were kept similar between starch and fiber diets within a given $\mathrm{CP}$ level. Because the portal absorption of AA is carried predominantly in plasma and no evidence exists for erythrocytes to be involved in liver AA flux (Lobley et al., 1996), the AA analysis was performed from plasma samples. The effect of different $\mathrm{N}$ intake levels on ruminant splanchnic metabolism has been extensively discussed in other studies (Lapierre et al., 2000; Raggio et al., 2004); thus, this discussion will focus mainly on the $\mathrm{CHO}$ effect and its possible interaction with the dietary CP level.

\section{Net Portal Fluxes}

Data from this study showed a greater proportion of feed $\mathrm{N}$ intake recovered as portal absorbed AA (NPA of TAA-N) when changing the main $\mathrm{CHO}$ from fiber to starch. However, our results confirm a lack of a direct sparing effect of starch diets on AA used by the PDV as energy fuels and suggest that the improvement in the NPA of TAA-N with starch versus fiber diets is rather the consequence of lower energy requirements by PDV along with a higher microbial $\mathrm{N}$ flow to the duodenum.

Total absorbed energy from the gastrointestinal tract (calculated from PDV measurements accord- 
Table 6. Net portal appearance (NPA), net hepatic flux (NHF), and net splanchnic release (NSR) of urea-N, ammonia-N, and AA in lactating Jersey cows fed the experimental diets ${ }^{1}$

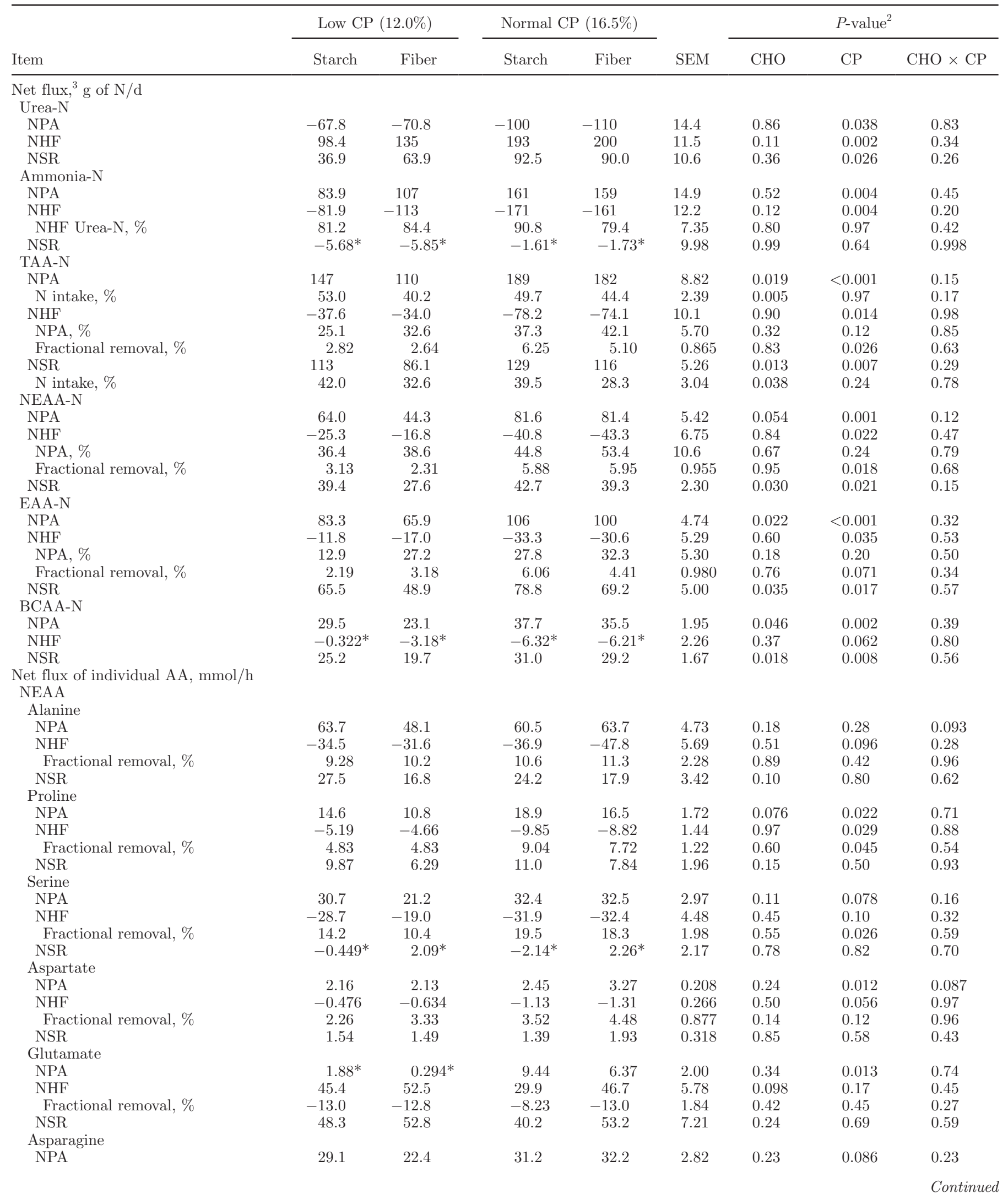


Table 6 (Continued). Net portal appearance (NPA), net hepatic flux (NHF), and net splanchnic release (NSR) of urea-N, ammonia-N, and AA in lactating Jersey cows fed the experimental $\operatorname{diets}^{1}$

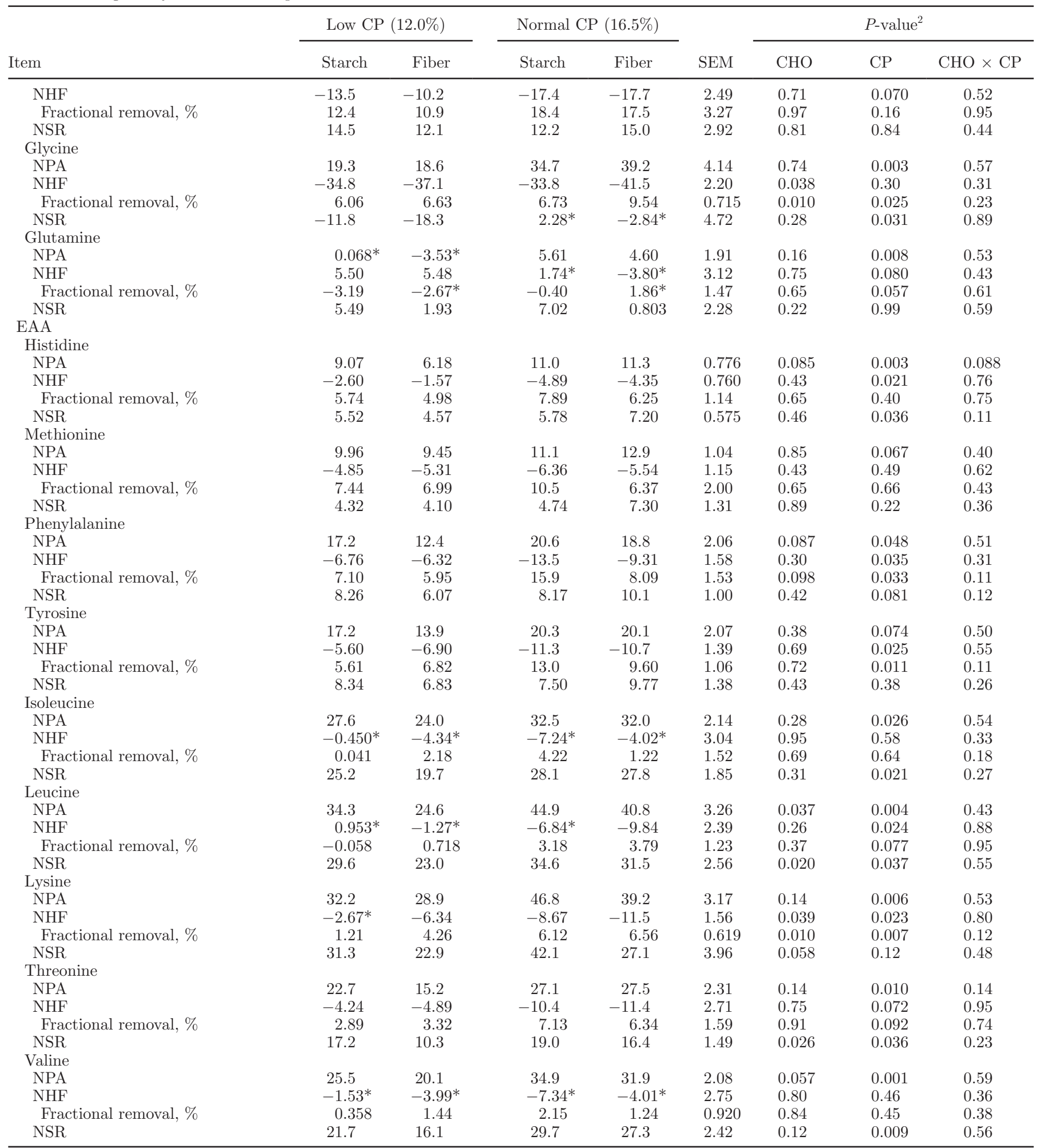

${ }^{1}$ Least squares means presented with pooled SEM $[\mathrm{n}=5$ for portal drained viscera (PDV) data, and $\mathrm{n}=4$ for NHF and NSR data]. ${ }^{2} \mathrm{CHO}=$ effect of dietary carbohydrate (starch or fiber); $\mathrm{CP}=$ effect of $\mathrm{CP}$.

${ }^{3}$ TAA-N = nitrogen from total AA (NEAA-N + EAA-N); NEEA-N = nitrogen from NEAA (Ala, Pro, Ser, Asp, Glu, Asn, Gly, and Gln); EAA-N = nitrogen from EAA (His, Met, Phe, Tyr, Ile, Leu, Lys, Thr, and Val); BCAA-N = nitrogen from branched-chain AA (Leu, Ile, and Val).

*Net fluxes not different from $0(P<0.05)$ according to the asymptotic CI within each treatment. 

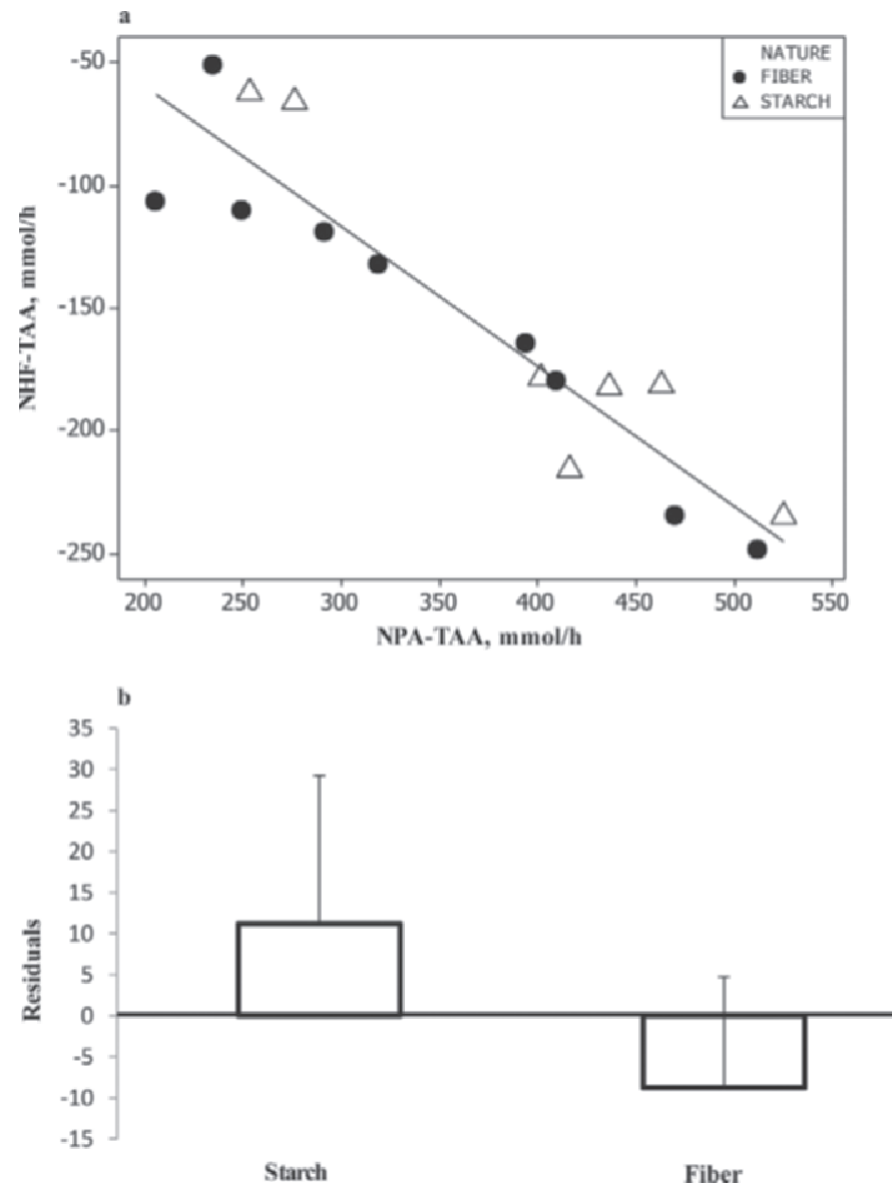

Figure 1. Net hepatic flux (NHF; mmol/h) of total AA (TAA) in Jersey lactating cows fed the experimental diets. (a) Net hepatic flux regressed against the net portal appearance $(\mathrm{NPA} ; \mathrm{mmol} / \mathrm{h})$ of TAA and adjusted for animal and period effects ffitted equation is NHF$\mathrm{TAA}=-0.569(\mathrm{SE}=0.060 ; P<0.001) \times \mathrm{NPA}-\mathrm{TAA}+54.2(\mathrm{SE}=$ $\left.22.8 ; P=0.032) ; \mathrm{R}^{2}=85.5\right]$; (b) residuals from the regression shown in panel a and according to the dietary carbohydrate composition (starch vs. fiber). Analysis of residuals shows that starch diets tended to increase $(P=0.091)$ the NHF of TAA (lower liver uptake) compared with diets rich in fiber.

ing to Loncke et al., 2011) was, as expected, similar across treatments and accounted for $77.0 \pm 4.76 \%$ of the calculated ME intake (using digestibility data from Cantalapiedra-Hijar et al., 2014) and for $118 \pm 7.22 \%$ of the theoretical $\mathrm{NE}_{\mathrm{L}}$ intake. Lower absorbed energy compared with ME intake was in agreement with other studies [68-74\% (Lindsay, 1993); $86.0 \pm 9.5 \%$ (Loncke et al., 2011)] and may originate from biases in the calculation of $\mathrm{ME}$ intake from digestible $\mathrm{OM}$ intake (Loncke et al., 2011) and methodological limits of the arteriovenous differences technique (Lindsay, 1993).

Despite similar absorbed energy across diets, fiber diets increased the energy expenditure of PDV by $14 \%$, on average, compared with starch diets. Reynolds et al. (1991a) and McLeod and Baldwin (2000) found that dietary NDF content increased the energy expenditure of PDV independently of the DMI. A higher gastrointestinal workload (Reynolds et al., 1991a) as well as a greater size of PDV (Bailey, 1986; McLeod and Baldwin, 2000) is expected as the dietary bulk and fiber content of diets increase. Moreover, although nonsignificant, the blood flow across the PDV was higher $(+9 \%)$ with fiber diets, compatible with a higher PDV size and energy expenditure (Reynolds et al., 1991a; Han et al., 2002).

The profile of energy-yielding nutrients absorbed into the portal vein changed according to $\mathrm{CHO}$ as empirically predicted by meta-analysis (Loncke et al., 2009). In particular, the higher NPA of glucose associated with starch diets was compensated by a higher NPA of acetate promoted by fiber diets. The glucogenic nature of starch diets was reflected by the higher insulin secretion (NPA of insulin) and concentration (van Knegsel et al., 2005) compared with fiber diets; however, the lower NPA of propionate found with starch versus fiber diets as well as the marked difference in NPA of butyrate across $\mathrm{CHO}$ was unexpected. Sucrose from molasses increased ruminal butyrate proportions (Kellogg and Owen, 1969) and thus a slightly higher NPA of butyrate could be expected with starch versus fiber diets. In addition, feeding diets hourly and at a restricted intake level may promote high rumen protozoa proliferation and thus a shift in the rumen VFA pattern toward butyrate at the expense of propionate (Brossard et al., 2004). Interestingly, the NPA of butyrate plus BHBA were similar among treatments. Because butyrate is an efficient energy source for rumen (Kristensen, 2005) and gut (Topping and Clifton, 2001) epithelia, as well as the major precursor for BHBA (Kristensen, 2005), a higher NPA of butyrate and lower NPA-BHBA with starch versus fiber diets agrees with the lower energy expenditure of PDV found with starch diets.

The observed differences in the profile of absorbed energy-yielding nutrients with $\mathrm{CHO}$ was accompanied by a significant increase in the proportion of dietary $\mathrm{N}$ recovered as TAA-N in the portal vein with starch versus fiber diets (51.4 vs. $42.3 \%$ ). This higher NPA of TAA-N was compatible with a greater milk $\mathrm{N}$ yield and whole-body Leu turnover (Cantalapiedra-Hijar et al., 2012) and could be the consequence of lower energy expenditure of PDV, and thus AA requirements, as the size of viscera decreases with lower dietary NDF content (Reynolds et al., 1991a; McLeod and Baldwin, 2000).

The loss of AA between intestinal absorption and their NPA is a result of AA oxidation and non-reabsorbed endogenous protein secretion (Lobley et al., 2003). The NEAA are used by the gut tissues mainly as an energy source, as opposed to the EAA, which are mostly used for protein synthesis (Lobley et al., 
2003). Therefore, specific responses of EAA versus NEAA may help explain the changes in PDV AA use for protein synthesis or oxidation. In the present study, although a tendency existed for NPA-NEAA to be higher in animals fed diets rich in starch versus fiber, none of the AA considered as the main energy fuels for PDV tissues (Glu, Gln, and Asp; Berthiaume et al., 2001) were significantly affected. This indicates that the effect of CHO on the NPA-TAA is not likely the consequence of a direct sparing effect of starch diets on AA catabolism by PDV.

Attempts to improve glucose supply to spare AA from PDV metabolism have not always been successful. No improvement in the NPA-TAA was measured when glucose was infused in the abomasum (Larsen and Kristensen, 2009; Freetly et al., 2010), duodenum (Krehbiel et al., 1996), or intravenously (Balcells et al., 1995). Conversely, encouraging results have been obtained when nutrient supply was altered by diet (starch vs. fiber) formulation [ $+68 \%$ higher NPA of TAA, nonsignificant (Seal et al., 1992); $+22 \%$ higher NPA of EAA, significant (Larsen and Kristensen, 2012)]. In this sense, starch diets has been shown to improve the efficiency of microbial N synthesis (Ouellet et al., 2002; Fanchone et al., 2013), as assumed by some feeding systems [CNCPS (Sniffen et al., 1992); DVE/OEB 2010 (Van Duinkerken et al., 2011); NorFor (Volden, 2011)] but not by others (NRC, 2001; INRA, 2007). A higher microbial $\mathrm{N}$ flow to the duodenum and, thus, NPA of TAA-N could be then expected with starch versus fiber diets above theoretical predictions (INRA, 2007). Interestingly, in the feeding trial of Cantalapiedra-Hijar et al. (2014), which used the same diets as in the current study, the microbial $\mathrm{N}$ flow to the duodenum was improved when changing from fiber to starch diets; this improvement was more than 2-fold higher at low $(24.5 \%)$ versus normal (10.5\%) CP contents, which is compatible with data obtained in the present study. In contrast, changes in $\mathrm{CHO}$ did not promote differences in the NPA of urea-N, in agreement with others (Larsen and Kristensen, 2012).

According to Lobley et al. (2003), the loss of EAA across PDV metabolism is more probably associated with incomplete reabsorption of endogenous protein (secretions and cellular desquamations) rather than with high rates of PDV protein turnover. However, no differences in endogenous fecal $\mathrm{N}$ secretion were observed between low and high-fiber diets in direct comparisons (Ouellet et al., 2002) or by meta-analysis (Marini et al., 2008). One hypothesis, based on the model by Hanigan et al. (2004), is that the increased anabolic use of AA by extrasplanchnic tissues would reduce the catabolic use of AA by the PDV, resulting in a higher NPA. Indeed, for some AA, such as the BCAA, the PDV may contribute to the catabolic regulation of AA balance (Lobley et al., 2003; El-Kadi et al., 2006). Interestingly, the arterial concentration of BCAA was lower $(-23 \%)$ with diets rich in starch versus fiber, but only at normal CP levels, which raises the hypothesis of a different mechanism by which starch diets improve the NPA-TAA based on the dietary CP levels.

\section{Net Hepatic Fluxes}

Our results show a tendency for diets rich in starch to decrease the NHF-TAA when standardizing data at similar NPA-TAA. This tendency did not seem to be driven by a direct sparing effect of glucogenic nutrients on hepatic AA uptake but more likely as a consequence of better utilization by extrahepatic tissues associated with high insulin concentrations.

Data in the literature show that the contribution of AA to hepatic gluconeogenesis can vary considerably in the fed dairy cow (6.1 to 20\%; Larsen and Kristensen, 2012 ) and this could logically have a non-negligible effect on the efficiency of $\mathrm{N}$ utilization and, thus, on protein requirements (Danfær et al., 1995). Because the contribution of AA to gluconeogenesis decreases as the insulin concentration (Brockman, 1990) and NPA of propionate increases (Danfær et al., 1995), a supply of glucogenic nutrients has been thought to decrease the uptake of AA by the liver (Danfær et al., 1995; Larsen and Kristensen, 2012). Moreover, it is believed that an increased NPA of glucose with diets rich in starch could be partly compensated for by a decrease in hepatic gluconeogenesis (Freetly et al., 2010), further sparing AA (Larsen and Kristensen, 2009).

No difference in the NHF of either total, NEAA-N or EAA-N was found between diets differing in CHO. However, because one of the main factors driving the AA liver uptake is their NPA (Reynolds, 2006), a residuals analysis from the regression of NHF-TAA on NPATAA was carried out to evaluate whether the $\mathrm{CHO}$ itself could affect the AA hepatic uptake, regardless of its positive effect on NPA-TAA (Figure 1b). Thus, at similar NPA-TAA, diets rich in starch versus fiber tended to promote a higher NHF-TAA (lower uptake). Likewise, Larsen and Kristensen (2012) found a similar NHF-TAA in ruminants fed a glucogenic compared with a ketogenic diet, despite a significantly higher NPA of EAA with the glucogenic diets. When no differences in NPA were observed (Huntington, 1989), diets rich in starch promoted a significantly lower $(-68 \%)$ $\alpha$-amino $\mathrm{N}$ hepatic uptake compared with diets rich in fiber. This would suggest an effect of $\mathrm{CHO}$ on liver AA metabolism in our study, hidden by differences in NPA.

The fractional removal of AA by the liver does not remain constant across different dietary and physiologi- 
cal conditions and can vary with changes in supply and requirements (Blouin et al., 2002). This was the case for most individual AA when dietary $\mathrm{CP}$ content increased. In contrast, fractional removal of AA by the liver was only modified by $\mathrm{CHO}$ for 2 AA: Gly and Lys. Because Lys (together with Leu) is the only nonglucogenic AA and the potential contribution of Gly to gluconeogenesis does not seem to be of quantitative importance (Larsen and Kristensen, 2012), our results do not indicate a lower use of AA for hepatic gluconeogenesis when feeding starch versus fiber diets. In practice, the major gluconeogenic AA substrates are the NEAA, alanine, glutamine (converted to glutamate), glycine, and serine (Wolff et al., 1972). Alanine has been proposed as the most important AA contributing to gluconeogenesis (Wolff et al., 1972; Larsen and Kristensen, 2013) but its net liver uptake was not modified by $\mathrm{CHO}$ in our study. Glycine was the only AA whose liver uptake increased when shifting from starch to fiber diets in one study (Larsen and Kristensen, 2012) and this could be related to the hepatic synthesis of hippuric acid (glycine conjugate of benzoic acid) as the dietary fiber increases (Martin, 1969). In contrast, no clear explanation was found in our study for changes in NHF of Lys across CHO.

Finally, as stated before for PDV, a lower net hepatic uptake of AA with starch diets can also be the consequence of better use by non-splanchnic tissues, as liver metabolism seems to be regulated not only by the feed supply (NPA) but also by the nutrients demand of peripheral tissues (Reynolds, 2006). Because the uptake of AA by muscle is stimulated by insulin concentrations in ruminants (see review by Brockman and Laarveld, 1986), lower hepatic AA uptake with starch versus fiber diets could be the consequence of better use of AA for protein synthesis.

\section{Net Splanchnic Flux}

The amount of energy released by the splanchnic tissues remained similar across dietary treatments and accounted for $91.4 \pm 4.83 \%$ of the theoretical NE intake. In addition, the only change in the profile of energy-yielding nutrients released by the splanchnic tissues was observed for butyrate and BHBA, whose splanchnic fluxes respond to $\mathrm{CHO}$, depending on the dietary CP level. In contrast, the improvement in milk $\mathrm{N}$ secretion $(+7 \%)$ found in our experiment when starch replaced fiber as the main $\mathrm{CHO}$ was accompanied by a greater NSR of TAA-N $(+22 \%)$; that is, a higher systemic availability of absorbed AA for the peripheral tissues at similar calculated $\mathrm{MP}$ and $\mathrm{NE}_{\mathrm{L}}$ intakes. In this sense, Larsen and Kristensen (2012) recently found a greater NSR-TAA (calculated values of 7 and $29 \%$, respectively) associated with higher milk $\mathrm{N}$ yield when postpartum cows (between 4 and 29 DIM) were fed a glucogenic diet versus a ketogenic diet, but the reduced number of observations ( $\mathrm{n}=2$ for the glucogenic diet) did not result in a significant effect. Likewise, Reynolds et al. (1991b) and Huntington et al. (1996) observed a higher (although nonsignificant) NSR of $\alpha$-amino N $(+17$ and $+24 \%$, respectively) when beef cattle were fed a glucogenic diet compared with a ketogenic diet at similar energy intakes. As far as we know, no more data exist in the literature comparing the posthepatic net flux of AA when animals are fed glucogenic versus ketogenic diets at similar energy and $\mathrm{N}$ intakes, but the few results found in the literature along with ours indicate that diets rich in starch can modify the net flux of AA presented to the peripheral (productive) tissues without remarkable changes in both energy and type of energy-yielding nutrients.

\section{CONCLUSIONS}

At similar $\mathrm{N}$ intake and total absorbed energy, the dietary carbohydrate composition affected the profile of portal absorbed energy-yielding nutrients as well as the net posthepatic availability of AA. In particular, this study confirmed previous results observing a higher milk $\mathrm{N}$ yield with starch versus fiber diets and demonstrated that the net splanchnic release of AA was significantly improved by formulating diets high in starch, regardless the dietary $\mathrm{N}$ content. The higher transfer of $\mathrm{N}$ from feed to milk with diets rich in starch compared with fiber seems not to be the consequence of a direct AA sparing effect of starch diets but rather the result of lower PDV energy requirements and higher microbial $\mathrm{N}$ flow to the duodenum. More studies are needed to clarify whether the AA use by peripheral tissues could have been improved by starch versus fiber diets, as suggested in this experiment. Results from this study may justify the need to evolve toward a nutrientbased system.

\section{ACKNOWLEDGMENTS}

G. Cantalapiedra-Hijar gratefully acknowledges the receipt of a scholarship from the PHASE department (INRA). We thank the Commission of the European Communities (Brussels, Belgium; project FP7KBBE-2007-1 "Rednex") and Adisseo (Commentry, France) for financial support; D. Durand, D. Remond, and P. Gaydier (all from UMR 1213 INRA-VetAgroSup, St Genès Champanelle, France) for animal surgery; C. Cossoul, A. S. Bage, V. Largeau, A. Thomas, S. Rudel, D. Roux, C. Mathevon, J. B. Temma, and L. Mouly (all from UMR 1213 INRA-VetAgroSup) for techni- 
cal assistance; and C. Barratt (University of Reading, Reading, UK) for her help in English translation.

\section{REFERENCES}

ARC (Agricultural Research Council). 1984. The nutrient requirements of ruminant livestock. Supplement no. 1. Commonwealth Agricultural Bureaux, Slough, UK.

Bailey, C. B. 1986. Growth of digestive organs and their contents in Holstein steers: Relation to body weight and diet. Can. J. Anim. Sci. 66:653-661.

Balcells, J., C. J. Seal, and D. S. Parker. 1995. Effect of intravenous glucose infusion on metabolism of portal-drained viscera in sheep fed a cereal/straw-based diet. J. Anim. Sci. 73:2146-2155.

Berthiaume, R., P. Dubreuil, M. Stevenson, B. W. McBride, and H. Lapierre. 2001. Intestinal disappearance and mesenteric and portal appearance of amino acids in dairy cows fed ruminally protected methionine. J. Dairy Sci. 84:194-203.

Blouin, J. P., J. F. Bernier, C. K. Reynolds, G. E. Lobley, P. Dubreuil, and H. Lapierre. 2002. Effect of supply of metabolizable protein on splanchnic fluxes of nutrients and hormones in lactating dairy cows. J. Dairy Sci. 85:2618-2630.

Brockman, R. P. 1990. Effect of insulin on the utilization of propionate in gluconeogenesis in sheep. Br. J. Nutr. 64:95-101.

Brockman, R. P., and B. Laarveld. 1986. Hormonal regulation of metabolism in ruminants; a review. Livest. Prod. Sci. 14:313-334.

Brossard, L., C. Martin, F. Chaucheyras-Durand, and T. L. B. Michalet-Doreau. 2004. Protozoa involved in butyric rather than lactic fermentative pattern during latent acidosis in sheep. Reprod. Nutr. Dev. 44:195-206.

Cantalapiedra-Hijar, G., J. L. Peyraud, S. Lemosquet, E. Molina-Alcaide, H. Boudra, P. Nozière, and I. Ortigues-Marty. 2014. Dietary carbohydrate composition modifies the milk $\mathrm{N}$ efficiency in late lactation cows fed crude protein diets. Animal 8:275-285.

Cantalapiedra-Hijar, G., I. Savary-Auzeloux, C. Cossoul, D. Durand, and I. Ortigues-Marty. 2012. Dietary energy source modifies the N utilization and the whole-body leucine kinetics in dairy cows. Page 114 in Book of Abstracts No. 18 of the 63rd Annual Meeting of the European Association for Animal Production, Bratislava, Slovakia. Wageningen Academic Publishers, Wageningen, the Netherlands.

Castillo, A. R., E. Kebreab, D. E. Beever, J. H. Barbi, J. D. Sutton, H. C. Kirby, and J. France. 2001. The effect of protein supplementation on nitrogen utilization in lactating dairy cows fed grass silage diets. J. Anim. Sci. 79:247-253.

Danfær, A., V. Tetens, and N. Agergaard. 1995. Review and an experimental study on the physiological and quantitative aspects of gluconeogenesis in lactating ruminants. Comp. Biochem. Physiol. B 111:201-210.

El-Kadi, S. W., R. L. Baldwin VI, N. E. Sunny, S. L. Owens, and B. J. Bequette. 2006. Intestinal protein supply alters amino acid, but not glucose, metabolism by the sheep gastrointestinal tract. J. Nutr. 136:1261-1269.

Fanchone, A., P. Nozière, J. Portelli, B. Duriot, V. Largeau, and M. Doreau. 2013. Effects of nitrogen underfeeding and energy source on nitrogen ruminal metabolism, digestion, and nitrogen partitioning in dairy cows. J. Anim. Sci. 91:895-906.

Freetly, H. C., C. L. Ferrell, and S. Archibeque. 2010. Net flux of amino acids across the portal-drained viscera and liver of the ewe during abomasal infusion of protein and glucose. J. Anim. Sci. 88:1093-1107.

Han, X. T., P. Nozière, D. Rémond, J. Chabrot, and M. Doreau. 2002. Respective effects of nutrient supply and dietary bulk on $\mathrm{O}_{2}$ uptake and nutrient net fluxes across rumen, mesenteric- and portaldrained viscera in ewes. J. Anim. Sci. 80:1362-1374.

Hanigan, M. D., L. A. Crompton, C. K. Reynolds, D. Wray-Cahen, M. A. Lomax, and J. France. 2005. Quantitative aspects of ruminant splanchnic metabolism as related to predicting animal performance. Anim. Sci. 80:23-32.

Hanigan, M. D., C. K. Reynolds, D. J. Humphries, B. Lupoli, and J. D. Sutton. 2004. A model of net amino acid absorption and utili- zation by the portal-drained viscera of the lactating dairy cow. J. Dairy Sci. 87:4247-4268.

Haque, M. N., H. Rulquin, and S. Lemosquet. 2013. Milk protein responses in dairy cows to changes in postruminal supplies of arginine, isoleucine, and valine. J. Dairy Sci. 96:420-430.

Huhtanen, P., and A. N. Hristov. 2009. A meta-analysis of the effects of dietary protein concentration and degradability on milk protein yield and milk N efficiency in dairy cows. J. Dairy Sci. 92:3222-3232.

Huntington, G. B. 1989. Hepatic urea synthesis and site and rate of urea removal from blood of beef steers fed alfalfa hay or a high concentrate diet. Can. J. Anim. Sci. 69:215-223.

Huntington, G. B., E. J. Zetina, J. M. Whitt, and W. Potts. 1996. Effects of dietary concentrate level on nutrient absorption, liver metabolism, and urea kinetics of beef steers fed isonitrogenous and isoenergetic diets. J. Anim. Sci. 74:908-916.

INRA (Institut national de la recherche agronomique). 2007. Alimentation des bovins, ovins et caprins-Besoins des animaux - Valeurs des aliments-Tables INRA 2007. Éditions Quae, Versailles, France.

Isserty, A., I. Ortigues, and D. Remond. 1998. Mesure des débits splanchniques par dilution de marqueur: Comparaison de quatre méthodes de dosage de l'acide para-amino hippurique. Reprod. Nutr. Dev. 38:93-106.

Katz, M. L., and E. N. Bergman. 1969. Simultaneous measurements of hepatic and portal venous blood flow in the sheep and dog. Am. J. Physiol. 216:946-952.

Kellogg, D. W., and F. G. Owen. 1969. Relation of ration sucrose level and grain content to lactation performance and rumen fermentation. J. Dairy Sci. 52:657-662.

Kelman, G. R. 1966. Digital computer subroutine for the conversion of oxygen tension into saturation. J. Appl. Physiol. 21:1375-1376.

Kraft, G., I. Ortigues-Marty, D. Durand, D. Rémond, T. Jardé, B. Bequette, and I. Savary-Auzeloux. 2011. Adaptations of hepatic amino acid uptake and net utilisation contributes to nitrogen economy or waste in lambs fed nitrogen- or energy-deficient diets. Animal 5:678-690.

Krehbiel, C. R., R. A. Britton, D. L. Harmon, J. P. Peters, R. A. Stock, and H. E. Grotjan. 1996. Effects of varying levels of duodenal or midjejunal glucose and 2-deoxyglucose infusion on small intestinal disappearance and net portal glucose flux in steers. J. Anim. Sci. 74:693-700.

Kristensen, N. B. 2005. Splanchnic metabolism of volatile fatty acids in the dairy cow. Anim. Sci. 80:3-10.

Lapierre, H., J. F. Bernier, P. Dubreuil, C. K. Reynolds, C. Farmer, D. R. Ouellet, and G. E. Lobley. 2000. The effect of feed intake level on splanchnic metabolism in growing beef steers. J. Anim. Sci. 78:1084-1099.

Lapierre, H., R. Berthiaume, G. Raggio, M. C. Thivierge, L. Doepel, D. Pacheco, P. Dubreuil, and G. E. Lobley. 2005. The route of absorbed nitrogen into milk protein. Anim. Sci. 80:11-22.

Larsen, M., and N. B. Kristensen. 2009. Effect of abomasal glucose infusion on splanchnic and whole-body glucose metabolism in periparturient dairy cows. J. Dairy Sci. 92:1071-1083.

Larsen, M., and N. B. Kristensen. 2012. Effects of glucogenic and ketogenic feeding strategies on splanchnic glucose and amino acid metabolism in postpartum transition Holstein cows. J. Dairy Sci. 95:5946-5960.

Larsen, M., and N. B. Kristensen. 2013. Precursors for liver gluconeogenesis in periparturient dairy cows. Animal 7:1640-1650.

Leiva, E., M. B. Hall, and H. H. Van Horn. 2000. Performance of dairy cattle fed citrus pulp or corn products as sources of neutral detergent-soluble carbohydrates. J. Dairy Sci. 83:2866-2875.

Lindsay, D. B. 1993. Making the sums add up-The importance of quantification in nutrition. Aust. J. Agric. Res. 44:479-493.

Lobley, G. E., A. Connell, D. K. Revell, B. J. Bequette, D. S. Brown, and A. G. Calder. 1996. Splanchnic-bed transfers of amino acids in sheep blood and plasma, as monitored through use of a multiple U- ${ }^{13}$ C-labelled amino acid mixture. Br. J. Nutr. 75:217-235.

Lobley, G. E., X. Shen, G. Le, D. M. Bremner, E. Milne, A. G. Calder, S. E. Anderson, and N. Dennison. 2003. Oxidation of essential 
amino acids by the ovine gastrointestinal tract. Br. J. Nutr. 89:617-629.

Loncke, C., P. Nozière, S. Amblard, S. Léger, J. Vernet, H. Lapierre, D. Sauvant, and I. Ortigues-Marty. 2011. From metabolisable energy to energy of absorbed nutrients: Quantitative comparison of models. Pages 233-242 in Modelling Nutrient Digestion and Utilisation in Farm Animals. Wageningen Academic Publishers, Wageningen, the Netherlands.

Loncke, C., I. Ortigues-Marty, J. Vernet, H. Lapierre, D. Sauvant, and P. Nozière. 2009. Empirical prediction of net portal appearance of volatile fatty acids, glucose, and their secondary metabolites ( $\beta$-hydroxybutyrate, lactate) from dietary characteristics in ruminants: A meta-analysis approach. J. Anim. Sci. 87:253-268.

Marini, J. C., D. G. Fox, and M. R. Murphy. 2008. Nitrogen transactions along the gastrointestinal tract of cattle: A meta-analytical approach. J. Anim. Sci. 86:660-679.

Martin, A. K. 1969. Urinary excretion of aromatic acids by sheep given diets containing different amounts of protein and roughage. Br. J. Nutr. 23:389-399.

McLeod, K. R., and R. L. Baldwin. 2000. Effects of diet forage:concentrate ratio and metabolizable energy intake on visceral organ growth and in vitro oxidative capacity of gut tissues in sheep. J. Anim. Sci. 78:760-770.

McLean, J. A. 1972. On the calculation of heat production from opencircuit calorimetric measurements. Br. J. Nutr. 27:597-600.

Ngo, T. T., A. P. H. Phan, C. F. Yam, and H. F. Lenhoff. 1982. Interference in determination of ammonia with the hypochloritealkaline phenol method of Berthelot. Anal. Chem. 54:46-49.

Nocek, J. E., and S. Tamminga. 1991. Site of digestion of starch in the gastrointestinal tract of dairy cows and its effect on milk yield and composition. J. Dairy Sci. 74:3598-3629.

NRC. 2001. Nutrient Requirements of Dairy Cattle. 7th rev. ed. Natl. Acad. Press, Washington, DC.

Ormsby, A. A. 1942. A direct colorimetric method for the determination of urea in blood and urine. J. Biol. Chem. 146:595-604.

Ortigues, I., D. Durand, and J. Lefaivre. 1994. Use of para-amino hippuric acid to measure blood flows through portal-drained-viscera, liver and hindquarters in sheep. J. Agric. Sci. 122:299-308.

Ouellet, D. R., M. Demers, G. Zuur, G. E. Lobley, J. R. Seoane, J. V. Nolan, and H. Lapierre. 2002. Effect of dietary fiber on endogenous nitrogen flows in lactating dairy cows. J. Dairy Sci. 85:3013-3025.

Paulmier, V., A. Boissy, M. Faure, I. Ortigues-Marty, I. Veissier, J. Cognie, D. Holopherne, and D. Durand. 2012. Evaluation et traitement de la douleur chez la vache suite à une intervention chirurgicale [Assessment and treatment of pain in dairy cows after a surgical intervention]. Rencontres autour des Recherches sur les Ruminants 19:330. (Abstr.)

Pinheiro, J. C., and D. M. Bates, S. DebRoy, D. Sarkar, and R Core team. 2008. nlme: Linear and nonlinear mixed effects models. $\mathrm{R}$ package version 3.1-89. R Foundation for Statistical Computing, Vienna, Austria.

R Development Core Team. 2009. R: A language and environment for statistical computing. Accessed July 15, 2013. http://www.Rproject.org.

Raggio, G., D. Pacheco, R. Berthiaume, G. E. Lobley, D. Pellerin, G. Allard, P. Dubreuil, and H. Lapierre. 2004. Effect of level of metabolizable protein on splanchnic flux of amino acids in lactating dairy cows. J. Dairy Sci. 87:3461-3472.
Reynolds, C. K. 2006. Splanchnic amino acid metabolism in ruminants. Pages 225-248 in Ruminant Physiology: Digestion, Metabolism and Impact of Nutrition on Gene Expression, Immunology and Stress. K. Sejrsen, T. Hvelplund, and M. O. Nielsen, ed. Wageningen Academic Publishers, Wageningen, the Netherlands.

Reynolds, C. K., G. B. Huntington, H. F. Tyrrell, and P. J. Reynolds 1988. Net metabolism of volatile fatty acids, D- $\beta$-hydroxybutyrate, nonesterified fatty acids, and blood gasses by portal-drained viscera and liver of lactating Holstein cows. J. Dairy Sci. 71:23952405.

Reynolds, C. K., H. F. Tyrrell, and P. J. Reynolds. 1991a. Effects of diet forage-to-concentrate ratio and intake on energy metabolism in growing beef heifers: Whole body energy and nitrogen balance and visceral heat production. J. Nutr. 121:994-1003.

Reynolds, C. K., H. F. Tyrrell, and P. J. Reynolds. 1991b. Effects of diet forage-to-concentrate ratio and intake on energy metabolism in growing beef heifers: Net nutrient metabolism by visceral tissues. J. Nutr. 121:1004-1015.

Rodríguez-López, J. M., G. Cantalapiedra-Hijar, D. Durand, A. Isserty-Thomas, and I. Ortigues-Marty. 2014. Influence of the paraaminohippuric acid analysis method on the net hepatic flux of nutrients in lactating cows. J. Anim. Sci. 92:1074-1082. http:// dx.doi.org/10.2527 jas2013-7359.

Rulquin, H., R. Vérité, and J. Guinard-Flament. 2001. Amino acids truly digestible in the small intestine: The AADI system for the dairy cow. Prod. Anim. 14:265-274.

Seal, C. J., D. S. Parker, and P. J. Avery. 1992. The effect of forage and forage-concentrate diets on rumen fermentation and metabolism of nutrients by the mesenteric- and portal-drained viscera in growing steers. Br. J. Nutr. 67:355-370.

Sniffen, C. J., J. D. O'Connor, P. J. Van Soest, D. G. Fox, and J. B Russell. 1992. A net carbohydrate and protein system for evaluating cattle diets: II. Carbohydrate and protein availability. J. Anim. Sci. 70:3562-3577.

Topping, D. L., and P. M. Clifton. 2001. Short-chain fatty acids and human colonic function: Roles of resistant starch and nonstarch polysaccharides. Physiol. Rev. 81:1031-1064.

van der Schoor, S. R., J. B. van Goudoever, B. Stoll, J. F. Henry, J. R. Rosenberger, D. G. Burrin, and P. J. Reeds. 2001. The pattern of intestinal substrate oxidation is altered by protein restriction in pigs. Gastroenterology 121:1167-1175.

Van Duinkerken, G., M. C. Blok, A. Bannink, J. W. Cone, J. Dijkstra, A. M. Van Vuuren, and S. Tamminga. 2011. Update of the Dutch protein evaluation system for ruminants: The DVE/OEB2010 system. J. Agric. Sci. 149:351-367.

van Knegsel, A. T. M., H. van den Brand, J. Dijkstra, S. Tamminga, and B. Kemp. 2005. Effect of dietary energy source on energy balance, production, metabolic disorders and reproduction in lactating dairy cattle. Reprod. Nutr. Dev. 45:665-688.

Volden, H. 2011. NorFor-The Nordic Feed Evaluation System. EAAP Publications No. 130. Wageningen Academic Publishers, Wageningen, the Netherlands.

Wolff, J. E., E. N. Bergman, and H. H. Williams. 1972. Net metabolism of plasma amino acids by liver and portal-drained viscera of fed sheep. Am. J. Physiol. 223:438-446. 